\title{
IMAGINÁRIO SOCIAL NORDESTINO E POLÍTICAS DE DESEN- VOLVIMENTO DO TURISMO NO NORDESTE BRASILEIRO
}

\author{
Eustógio Wanderley Correia Dantas*
}

\section{RESUMO:}

A atividade turística, no final dos anos 1980, recebe especial atenção das políticas de desenvolvimento adotadas pelos estados nordestinos brasileiros. No cerne do PRODETUR-NE, projeto de dimensão regional, são alavancadas políticas públicas de caráter local (Estadual) e evidenciadoras do turismo como atividade econômica associada à pauta de desenvolvimento da região. O intento do presente trabalho é o de apreender os elementos motivadores da transformação de uma região não turística em uma região com "vocação" turística. O cerne da análise será o de vincular a opção ou não por dadas políticas públicas de desenvolvimento às representações coletivas da sociedade local em relação ao semi-árido. Nestes termos, a compreensão do acima exposto explicar-se-á ao recorrer à interpretação do imaginário social nordestino no tempo, enfatizando sua redefinição nos últimos anos, graças à indicação do semi-árido como virtualidade e em contraposição à imagem associada à seca, sinônimo de miséria, fome... Esta transformação de caráter simbólico potencializará quadro político (reforma constitucional) e econômico (nos termos do "city marketing") que dará margem ao processo de turistificação do Nordeste brasileiro, e este artigo tratará, em especial, do caso do Ceará.

\section{PALAVRAS-CHAVE:}

Imaginário Social; Turismo; Políticas Públicas.

\section{ABSTRACT:}

Touristic activity has received special attention within the development policies led by Northeastern States of Brazil since the end of the 1980's. In the centre of the PRODETUR-NE, a project of regional scope, public policies of a local character occurring within the State sphere have been stimulated, and tourism has been evidenced as an economic activity associated with the development aims set to the region. The intent of this paper is to apprehend the motivating factors behind the transformation of a non-touristic region into a region with a touristic "vocation". The essence of the analysis lies in the association between the adoption or not of certain public policies towards development and the collective representations of local society in relation to the semi-arid. In this way, the explanation for the understanding of such a transformation will be found in the Northeastern social imaginary along time, with emphasis on its redefinition over the last years, thanks to the association of the semi-arid as a place of virtue instead of one characterized by images that are usually related to droughts, misery, hunger...This transformation of a symbolic nature will make possible a situation that is both political (constitutional reform) and economic (in terms of "city marketing") which will give way to the action of turning the Northeast region into a touristic region, especially as regards the State of Ceará.

\section{KEY WORDS:}

Social imaginary; Tourism; Public policies. 


\section{Considerações Iniciais}

A problemática de valorização contemporânea das zonas de praia instaura discussões que abalam a imagem tradicional do Nordeste brasileiro, com passagem de uma imagem associada à pobreza para outra de caráter sobretudo turístico, vinculada ao sol, às jangadas e aos coqueirais (ALMEIDA, 1994).

Tal abalo se relaciona a um processo de valorização das zonas de praia dos Países do Sul, em via de desenvolvimento, como destinação turística, ao concentrar, nestas áreas, mais de $90 \%$ do fluxo turístico internacional: 500 milhões de turistas, sem contar os contingentes mais representativos do fluxo de caráter nacional (CAZES, 1999).

De acordo com este raciocínio, a turistificação dos litorais colocaria em xeque - imaginário social representativo dos discursos regionalistas associados à Região Nordeste, notadamente aqueles inscritos em quadro natural e histórico, responsáveis pela produção de toda uma série de mitos e do qual ele se nutre: o mito da existência de um povo forte, o Nordestino, que luta contra o meio semi-árido, o sertão, para construir sua sociedade, como se encontra expresso em Euclides da Cunha (1983).

\section{O Imaginário Social Nordestino}

A modificação do olhar da sociedade local face ao semi-árido marca a consubstanciação do conflito entre dois quadros simbólicos contraditórios. O primeiro quadro simbólico, o mais antigo, indica discurso que reforça um conjunto de imagens negativas do semi-árido em benefício da oligarquia agrária. O segundo quadro simbólico, o mais recente, indica novo discurso relacionado à virtualidade dos espaços semiáridos, construindo uma imagem positiva vinculada aos interesses de grupo de empreendedores ligados à agricultura irrigada e, naquilo que nos interessa diretamente, ao turismo.

\subsection{Quadro simbólico reforçando imagem negativa do semi-árido}

$O$ discurso fundamentador da imagem negativa do semi-árido encontra suas raízes em documentos antigos (principalmente as cartas reais) e relatos de viagem pautados em lógica determinista, remetendo a um quadro natural perverso, marcado pela semi-aridez e pelas secas cíclicas, vitimador do homem.

Um determinado quadro socioespacial específico é evidenciado a partir desta idéia fundadora, aquele marcado por um tipo de organização espacial e por um sistema de atores atrelados às especificidades do ecossistema semi-árido. Para Castro (1997a), significa a constituição do imaginário social da seca do Nordeste como uma tragédia socioeconômica a suscitar consciência coletiva apoiada nas intempéries climáticas.

Baseando-nos em Castro (1997a; 1997b), pode-se afirmar que a natureza, fundamento geográfico da produção, adquire importância como base material da construção do imaginário sóciopolítico e como recurso ideológico empregado em benefício de dados atores. No primeiro caso, o imaginário surge no momento em que a seca se torna uma referência, representando simbolicamente, de um lado, a região Nordeste tocada por uma natureza hostil que suscita problemas socioeconômicos (a fome, a miséria, o subdesenvolvimento) e, de outro lado, criando um imaginário político socialmente homogeneizador e eficaz no plano institucional para obtenção de recursos e de poder. No segundo caso, a lógica de naturalização da realidade baseia-se em importante recurso ideológico utilizado pela elite local no sentido de obter ajudas e subvenções da União, utilizadas, sobretudo, para manter o status quo.

Pode-se concluir que a oligarquia do Nordeste soube tirar proveito do discurso de caráter determinista para se inserir em um modelo de constituição de um Estado Nacional. Esta inserção, fundada sobre um discurso regionalista, nasce, conforme Castro (1997a), 
Imaginário social nordestino e políticas de

das clivagens da dominação da Região Sudeste e significa simplesmente uma luta por recursos capazes de fundamentar o poder simbólico de afirmação e de identidade da elite face aos outros segmentos da sociedade local.

A inserção obtida em virtude deste discurso regionalista evidencia um sistema socioespacial dependente do auxílio das subvenções do governo federal, permitindo, grosso modo:

- a construção de vias capazes de promover a integração do sertão ao mercado: as vias férreas, as vias estatais ( $\left.C e^{\prime} s\right)$, as vias federais $\left(B r^{\prime} s\right)$, bem como as vias secundárias;

- o estabelecimento e/ou criação de organismos públicos federais no Nordeste, e sobretudo nas capitais, e de instituições públicas como universidades, bancos ..., a criação de organismos de planejamento regional e de financiamento como o Departamento Nacional de Obras Contra as Secas (DNOCS), a Superintendência de Desenvolvimento do Nordeste (SUDENE) e o Banco do Nordeste do Brasil (BNB). 1960.

- a política de industrialização dos anos

Nessa época, diferentemente de outras cidades litorâneas dos países em via de desenvolvimento, as cidades litorâneas do Nordeste não se enquadravam na lógica de valorização turística. Os fluxos notados nesta região são reduzidos, de caráter fortemente nacional, e concentrados em certas cidades, sendo Salvador o principal exemplo deste período.

Tal orientação vincula-se ao modelo de desenvolvimento adotado no Brasil. Ao contrário de países como o México, no qual a indústria e o turismo são associados aos planos de desenvolvimento, no Brasil, a atividade turística não suscita, até primeira metade dos anos 1980, uma política global de desenvolvimento.

No Nordeste brasileiro, as políticas engajadas em matéria de turismo, são, por conseguinte, pontuais e desarticuladas. Para Paiva (1998), elas representam, inicialmente, políticas empreendidas pela CTI/NE, ONG criada em 1969, e, posteriormente, políticas publicitárias realizadas pelo BNB na difusão do Nordeste como destinação turística. Na escala nacional, a EMBRATUR, criada em 1966, não escapa a esta regra. Ela focava suas ações nos centros tradicionais de recepção, difundindo-os precariamente devido à inexistência de recursos e ausência de um plano estratégico de marketing em escala internacional.

O Brasil optou por uma única via de desenvolvimento, contida inicialmente nos planos de Substituição de Importações dos anos 1940 e continuada pelo governo militar dos anos 1960 até início dos anos 1980. Conforme orientações da SUDENE, este gênero de política, essencialmente fundada na industrialização, atingiu o Nordeste nos anos 1960.

A indicação da indústria como força motriz da política de desenvolvimento econômico regional suscita fracos investimentos na construção de quadro favorável à exploração turística. Os governos locais, seduzidos pelo paradigma da industrialização, são induzidos a colocar em segundo plano ou simplesmente negligenciam as potencialidades turísticas do Nordeste. Os esforços são concentrados, durante este período, no sentido de obter subvenções do governo federal para o estabelecimento de indústrias.

O quadro de secundarização da atividade turística é tratado, no caso da oligarquia cearense, por Coriolano (1989). Na análise dos planos de governo dos anos 1970, a autora indica um quadro fazendo, de um lado, referência superficial ao turismo, o Plano de Governo do Estado do Ceará (PLAGEC/1971), primeiro plano mencionando a atividade turística no Ceará e que se limita a sublinhar a falta de infra-estrutura turística e, de outro lado, tomando consciência de sua importância, o Plano Qüinqüenal de Desenvolvimento do Estado do Ceará de 1975 (PLANDECE/1975), o 
primeiro plano definindo os objetivos do desenvolvimento turístico no Ceará, o II Plano de Metas Governamentais de 1979 (II PLAMEG/ 1979), o Plano Integrado de Desenvolvimento Turístico do Estado do Ceará de 1979 (PIDTCE/1979), que apresenta um diagnóstico detalhado dos espaços turísticos existentes no Ceará.

Conservando seu caráter inovador, os citados planos não suscitaram políticas de desenvolvimento de turismo no Ceará. Observase, portanto, uma simples tomada de consciência não seguida de investimentos significativos neste domínio, denotando-se concentração de esforço na implantação de política atinente à industrialização e ao fortalecimento da estrutura produtiva do sertão. Baseado neste exemplo pode-se concluir que, influenciados por quadro de imagens negativas associadas ao semi-árido, a elite local (leia-se nordestina) se tornou prisioneira de lógica de valorização associada a esta zona. A valorização do espaço nordestino só se justificava, nesta época, com a realização de políticas públicas de planejamento do espaço, associadas ao imaginário social da seca e à racionalidade: a) do DNOCS, visando combater os problemas gerados pelas secas com a construção de vias e principalmente de açudes; b) da SUDENE, buscando superar os problemas da região com a industrialização, instalando fábricas nas capitais, privilegiando cidades como Salvador, Recife e Fortaleza e reforçando, conseqüentemente, o desequilíbrio socioespacial na escala estadual.

Tal fortalecimento, associado à formação de quadro socioespacial específico, é basilar na constituição das práticas marítimas modernas, a saber, os banhos de mar e, principalmente, o veraneio. Percebese a eclosão de um gênero de maritimidade relacionada à demanda local de grupo fortemente marcado pelos costumes europeus (elite), dado representativo de conflito instituído com práticas marítimas preexistentes (tradicionais), o porto e principalmente a pesca (DANTAS, 2004).

\subsection{Quadro simbólico reforçando imagem positiva do semi-árido}

Em virtude da falência do modelo de estado moderno no Brasil, na segunda metade dos anos 1980, as políticas públicas de planejamento indicadas anteriormente se mostram inadequadas. Com a reforma constitucional de 1989, o modelo centralizador e ditatorial de governo é substituído por modelo democrático a permitir, de um lado, a transferência de recursos controlados pelo governo central para os estados e municípios e, de outro lado, a possibilidade de captação direta de recursos financeiros no estrangeiro. Estes dois aspectos são basilares para a constituição de uma lógica contemporânea, na qual os estados brasileiros passam a estruturar e assegurar as políticas locais de desenvolvimento. Significa o fim do modelo representativo de uma articulação dependente das escalas local e regional à escala nacional, na medida em que a reforma constitucional permitiu o estabelecimento de relações mais amplas, integrando a escala internacional.

A inserção do Nordeste nesta escala implica no abalo do imaginário da seca como tragédia, haja vista seu conteúdo simbólico encontrar-se racionalmente esgotado (CASTRO, 1997b), não tendo peso face à lógica que inclui o Brasil no sistema mundo como produtor de tecnologia intermediária e aberto às inovações tecnológicas (BECKER; EGLER, 1992).

Para Castro (1999b), tal abalo consubstancia novos espaços de produção, um espaço econômico, social e político de resistência fundado na agricultura irrigada e no turismo, que evidenciam novos atores regionais: de um lado, segmento importante da elite política, notadamente os detentores de grande poder de assimilação e reprodução e, de outro, pequeno número de empreendedores privados e funcionários da administração pública.

Os atores supracitados são agentes e depositários de novo discurso, veiculado no 
Imaginário social nordestino e políticas de

meio empresarial por revistas e jornais, que exploram aspectos ligados às possibilidades oferecidas pelo Nordeste aos investimentos privados, tanto pelos seus recursos naturais quanto pela sua localização (proximidade) em relação ao mercado internacional.

Nestes termos, indica-se discurso de caráter técnico associado ao semi-árido e versando sobre: a) a ausência de chuvas e as taxas de insolação elevadas como dado importante e positivo no desenvolvimento da agricultura irrigada - o primeiro aspecto impedindo a reprodução dos insetos nocivos e o segundo, associado à fertilidade do solo, permitindo aumento da produtividade agrícola; b) a paisagem litorânea e o clima como importantes mercadorias turística - as belas paisagens e o sol (sinônimo de ausência de chuvas associado a temperaturas elevadas).

Embora os atores até então evidenciados abalem o pacto oligárquico existente na região, eles não conseguem tomar o poder em escala regional, diferentemente do ocorrido com a oligarquia algodoeira pecuarista do sertão ao desbancar os Senhores de Engenho da zona da mata (OLIVEIRA, 1981). Conforme Castro (1997b), aqueles atores são frágeis em termos políticos, dado gerador de necessidade de estabelecimento de alianças com outros segmentos políticos e administrativos para obter representatividade.

O recurso ao ocorrido no Ceará ilustra bem as transformações ocorridas no sentido de viabilizar a atividade turística na região. Neste estado, as alianças políticas conduziram grupo de empresários originários do Centro Industrial do Ceará (CIC) ao poder. Constata-se o sucesso de estratégia empreendida em 1978, com a eleição do presidente do $\mathrm{CIC}$ independente da Federação das Indústrias do Estado do Ceará (FIEC) e relacionada a interesse de jovens empresários em estabelecer um diálogo com o governo, em outros termos, uma busca de inserção política.

A partir desta busca, este grupo de empresários obtiveram algumas conquistas em escala local. Em um primeiro momento, dá-se a participação do CIC (grupo de técnicos e intelectuais) no governo de Gonzaga Mota (1983-1987): governo de ruptura com os coronéis. Em um segundo momento, uma composição política para as eleições governamentais de 1987 culmina na eleição de antigo presidente do CIC, o empresário Tasso Jereissati. Este tipo de composição afirma-se de maneira tal no Ceará, que o grupo supracitado permanece no poder por vinte anos: Tasso Jereissati no primeiro mandato (1987-1991), Ciro Gomes (1991-1995), Tasso Jereissati no segundo mandato (1996-1999), Tasso Jereissati no terceiro mandato (1999-2003) e Lúcio Alcântara (2003-2007).

O Ceará torna-se um paradigma para a região Nordeste, ao apostar em práticas políticas inovadoras como o Programa de Desenvolvimento do Turismo em Zona Prioritária do Ceará (PRODETURIS) de 1989. O citado projeto valoriza as praias como mercadoria turística antes do Programa de Ação Para o Desenvolvimento do Turismo do Nordeste (PRODETUR-NE) de 1992, caracterizando-se, portanto, como pioneiro neste domínio e totalmente financiado pelo governo do Ceará, que o considera um guia para os empreendedores, um indicador para os programas oficiais e para as políticas de planejamento turístico para o litoral cearense.

O novo pacto oligárquico no Nordeste possibilita a obtenção de recursos financeiros em escala internacional e a partir de parcerias estabelecidas entre os governos locais/organismos regionais (notadamente o Banco do Nordeste) e os organismos internacionais de financiamento, principalmente o Banco Interamericano de Desenvolvimento (BID). 
O desdobramento desta racionalidade é indicado em documento do Plano Nacional de Ordenamento Territorial (PNOT, 2006), documento constante em anexo e concernente à Região Nordeste e seus "fronts" de modernização (publicado na íntegra in. DANTAS et all, 2006b). O referido fundamentará nossas reflexões, posto evidenciar, na instituição de política de desenvolvimento turístico do Nordeste, lógica de investimentos do poder público e da iniciativa privada.

\section{No domínio dos fixos: investimentos do poder público}

Os investimentos públicos são os alavancadores da política de desenvolvimento. Conforme o BNDS, na primeira fase do PRODETUR (intitulado PRODETUR I, haja vista notar-se continuidade do mesmo com implantação do PRODETUR II e, mais recente, do PRODETUR III), até o ano de 2005, previa-se investimentos da ordem de 900 milhões de reais nos estados nordestinos, distribuídas as maiores parcelas para a Bahia (300 milhões de reais) e o Ceará (160 milhões de reais), totalizando $51 \%$ do volume de recursos totais. Os restantes $49 \%$ distribuídos, em ordem decrescente, entre os estados de Sergipe (76 milhões de reais), Maranhão (74 milhões de reais), Alagoas (71 milhões de reais), Pernambuco (64 milhões de reais), Paraíba (54 milhões de reais), Piauí (54 milhões de reais) e Rio Grande do Norte (47 milhões de reais) (Tabela 1 ). Baseado em Relatório Final do BNB este quadro muda e percebe-se, grosso modo, distribuição real dos recursos (investido) com valores superiores ao previsto. Nesta distribuição continuam a se destacar os estado da Bahia (139,06 milhões de dólares) e do Ceará (88,339 milhões de dólares), correspondendo a $57,33 \%$ do volume de recursos totais, cabendo os restantes $42,67 \%$ aos demais estados em ordem decrescente: Sergipe $(32,604$ milhões de dólares), Pernambuco $(30,763$ milhões de dólares), Alagoas $(27,612$ milhões de dólares), Maranhão $(26,599$ milhões de dólares), Rio Grande do Norte $(22,333$ milhões de dólares), Paraíba (19,997 milhões de dólares) e Piauí $(8,849$ milhões de dólares).

No redimensionamento da distribuição de recursos do PRODETUR I, na comparação entre valores previstos e investidos, merecem destaque Pernambuco e Rio Grande do Norte. Os dois estados, no tocante aos valores previstos, ocupavam, respectivamente, a sexta e a última posição, passando a ocupar, na consideração dos valores investidos, a quarta e sétima posições.

No concernente aos valores investidos pelos governos locais em parceria com organismos regionais e nacionais, torna-se impossível comparação entre os valores previstos e investidos. A não indicação dos valores previstos para a totalidade dos estados inviabiliza análise comparativa pertinente. Entretanto, interessante frisar participação forte destes estados. Os estados da Bahia $(75,505$ milhões de dólares) e do Ceará (53,428 milhões de dólares) continuam na liderança, concentrando $56,21 \%$ do total. Dos demais convém ressaltar desenvoltura do governo do Rio Grande do Norte (15,907 milhões de dólares) que ocupa a quarta posição, suplantando Alagoas (14,746 milhões de dólares), Maranhão (14,345 milhões de dólares), Paraíba (12,786 milhões de dólares), Piauí (12,274 milhões de dólares) e Pernambuco (11,212 milhões de dólares), perdendo unicamente para o terceiro classificado, Sergipe $(18,153$ milhões de dólares). 
Imaginário social nordestino e políticas de

Tabela 1 - Investimentos do PRODETUR I e dos Governos Locais

\begin{tabular}{|l|c|c|c|c|}
\hline \multirow{2}{*}{ ESTADO } & \multicolumn{2}{c|}{$\begin{array}{c}\text { PREVISTO (*) } \\
\text { (milhões R\$) }\end{array}$} & \multicolumn{2}{c|}{$\begin{array}{c}\text { INVESTIDO (**) } \\
\text { (milhões U\$) }\end{array}$} \\
\cline { 2 - 5 } & BID & LOCAL & BID & 14,756 \\
\hline Alagoas & 71 & - & 27,612 & 75,505 \\
\hline Bahia & 300 & 200 & 139,06 & 53,428 \\
\hline Ceará & 160 & - & 88,339 & 14,345 \\
\hline Maranhão & 74 & - & 26,599 & 12,786 \\
\hline Paraíba & 54 & 295 & 19,997 & 11,212 \\
\hline Pemambuos & 64 & 4,1 & 30,763 & 12,274 \\
\hline Piauí & 54 & - & 8,849 & 15,907 \\
\hline Rio Grande do Norte & 47 & - & 22,333 & 18,153 \\
\hline Sergipe & 76 & 282,981 & 32,604 & 229,366 \\
\hline ToTAL & 900 & - & 396,602 & \\
\hline
\end{tabular}

Fonte: BNDS, 2005 e Relatório Final do BNB, 2005.

Os valores envolvidos, além de distribuição desigual por estado, são direcionados a componentes diferenciados, englobando, nos termos indicados pelo Relatório Final do BNB, quatro componentes: componente $A$, desenvolvimento institucional; componente $\mathrm{B}$, obras múltiplas em infraestrutura básica e serviços públicos; componente C, melhoramento de aeroportos e componente D, estudos e projetos.

A consideração da variável componente indica quadro caracterizador de investimentos concentrados em infra-estrutura potencializadora da atividade turística no Nordeste. Percebe-se, na análise da Figura 1, importância dos investimentos, na ordem decrescente, no quesito aeroporto, saneamento e transportes, considerados os valores investidos pelo BID e local. No cômputo geral, o primeiro e terceiro quesitos somados correspondem a US\$218,625 milhões (BID) e US\$ 147,032 milhões (local), suplantando os valores atribuídos ao quesito saneamento: US\$ 118,256 milhões (BID) e US\$ 43,012 milhões (local). Tal lógica deslancha na caracterização de racionalidade determinante da produção de espaço da circulação, fundamentado na construção de aeroportos associados às vias litorâneas, os primeiros especializados na recepção de fluxos turísticos e as segundas garantidoras da distribuição destes fluxos nos espaços litorâneos.

Figura 1 - Valores Aplicados Pelo PRODETUR I Por Componente e Fonte

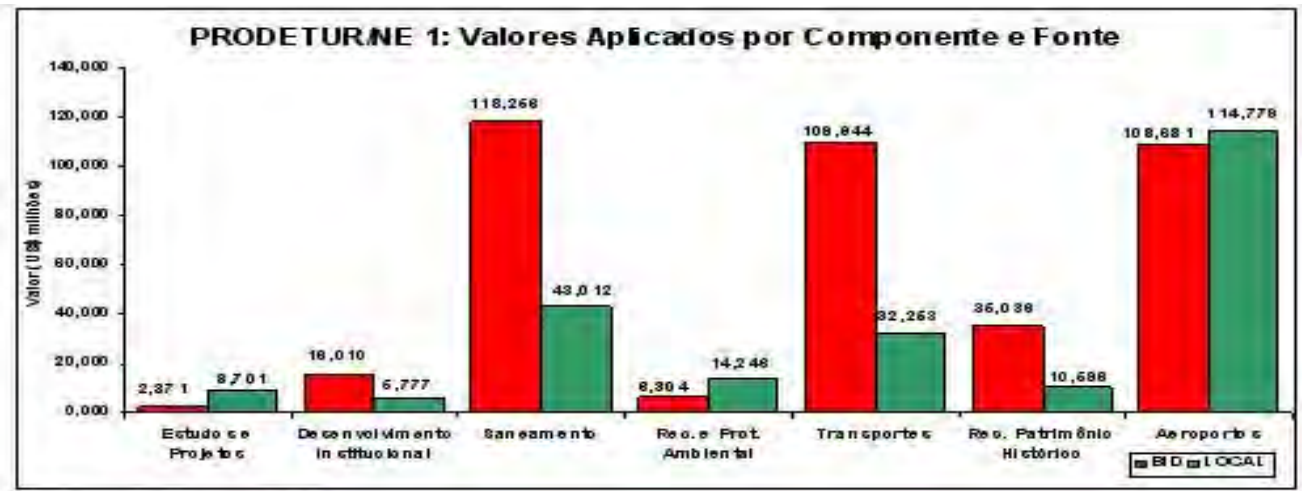

Fonte BNB, 2005 
Tal racionalidade é mais visível nos estados da Bahia e Ceará, cujos investimentos em aeroportos e transporte, com a indicação dos valores envolvidos nas políticas adotadas nos dois estado, refletem níveis de concentração próximos ou superiores aos valores investidos nos demais estados do Nordeste, exceto Rio Grande do Norte e Pernambuco, merecedores de destaque na figura 2.

No quesito melhoramento de aeroporto, há a construção, reforma ou ampliação de oito aeroportos nas cidades de São Luiz, Fortaleza, Natal, Recife, Aracajú e Salvador, com volume de recursos da ordem de US\$108,681 milhões (local) e US\$114,774 milhões (BID) (ver Figura 1). Na Bahia esta lógica amplia-se com construção de dois aeroportos nas cidades de Porto Seguro e Lençóis. Convém ressaltar, ainda, que dos aeroportos beneficiados, três passaram da qualidade de regionais à de internacionais, especificamente o Aeroporto Cunha Machado/MA, o Aeroporto Pinto Martins/ CE e o Aeroporto de Porto Seguro/BA. Merece destaque, nos termos supracitados, o volume de recursos investido na Bahia e no Ceará, respectivamente, quatro e duas vezes e meia superiores ao valor aplicado nos demais estados do Nordeste (Figura 2).

Quanto ao quesito transporte, tem-se a construção de um conjunto de vias litorâneas (Estruturante/CE, RN-063/RN, SE-100/SE, BA001 Illhéus-Itacaré). Embora os valores envolvidos não sejam superiores ao do Nordeste, apresentam-se próximos: Bahia e Ceará com, respectivamente, $10 \%$ abaixo e metade do valor envolvido nos demais estados do Nordeste (Figura 2).

Figura 2 - Investimento no Melhoramento de Aeroporto e de Transportes na Bahia, Ceará, Pernambuco e Rio Grande do Norte.

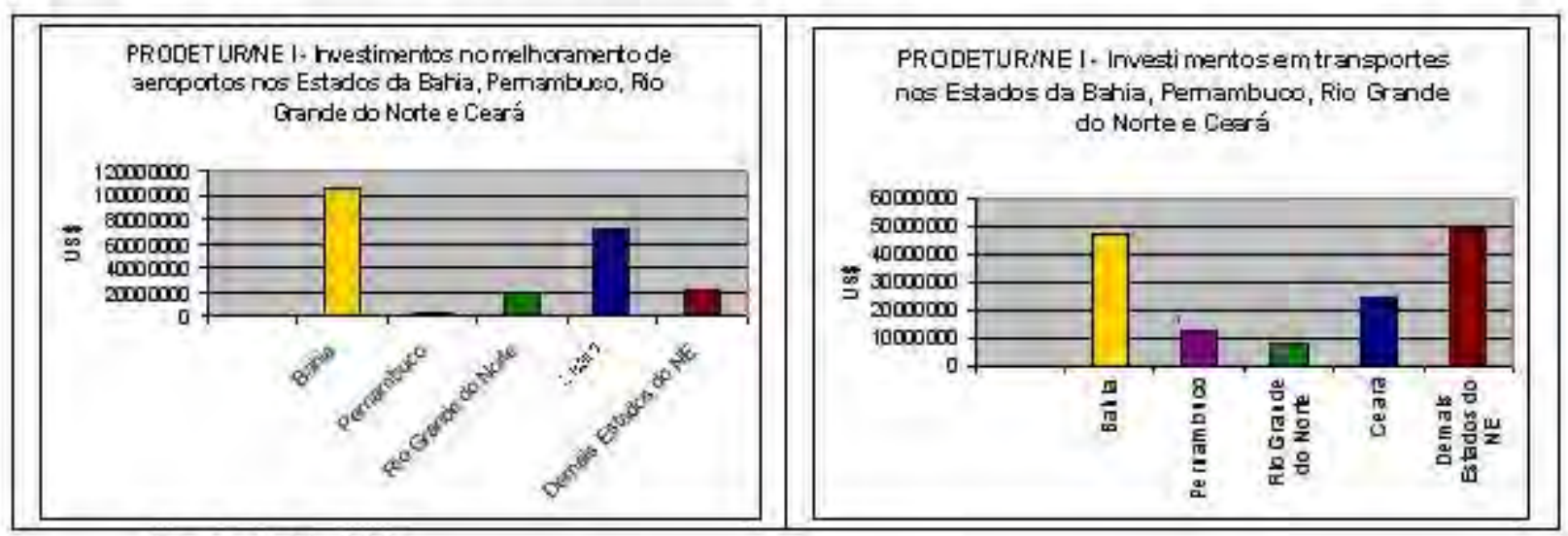

Fonte BNB, 2005.

O volume de recursos supramencionado por componente alavancou uma política de constituição dos Pólos de Desenvolvimento de Turismo no Nordeste brasileiro, perfazendo um total de 12 pólos concentrados nos nove estados nordestinos: Maranhão (Pólo São Luis), Piauí (Pólo Costa do Delta), Ceará (Pólo Ceará Costa do Sol), Rio Grande do Norte (Pólo Costa das Dunas), Paraíba (Pólo Costa das Piscinas), Pernambuco (Pólo Costa dos Arrecifes), Alagoas (Pólo Costa Dourada), Sergipe ( Pólo Costa dos Coqueirais) e Bahia (Pólos Salvador e Entorno, Litoral Sul, Costa do Descobrimento e Chapada da Diamantina), o único a dispor de pólo turístico de caráter não litorâneo (Chapada Diamantina) (Figura 3). 
Figura 3 - Pólos de Turismo no Nordeste Brasileiro

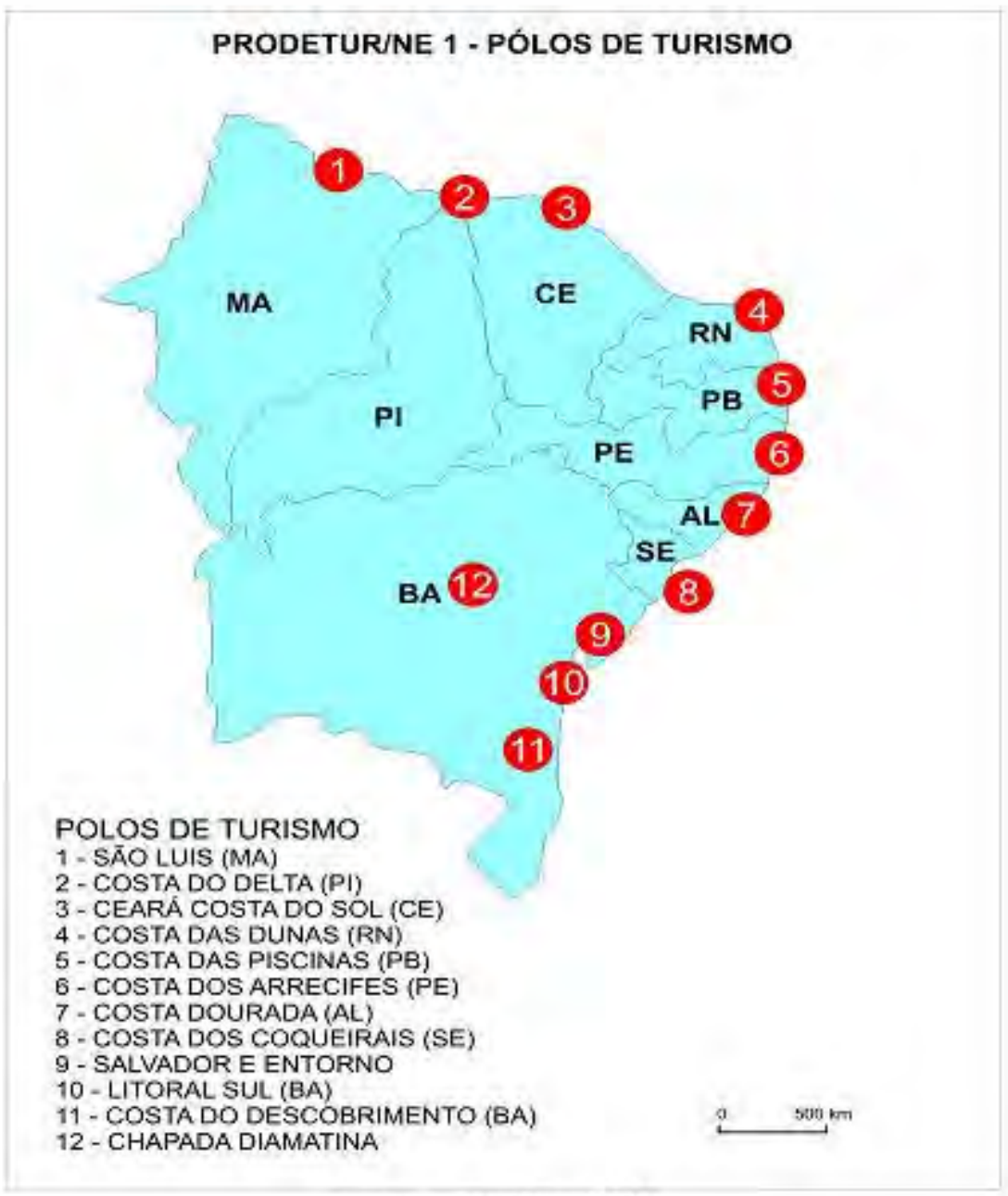

Fonte: PNOT, 2006.

3. No domínio dos fixos: investimentos da iniciativa privada

Os investimentos da iniciativa privada beneficiam-se dos investimentos públicos no domínio da infra-estrutura turística, consolidando e ou diversificando suas ações na zona costeira.
Para apreender esta racionalidade podemos envolver, à priori, dados relacionados ao setor hoteleiro. Tal gênero de atividade se beneficia imediatamente da nova lógica de ordenação do território, implantando unidades hoteleiras, principalmente nas capitais litorâneas nordestinas. Lamentavelmente, posto que os dados apresentados pelo PDITS do Pólo 
Costa dos Arrecifes se relacionam à totalidade de Pernambuco, não há a possibilidade de estabelecimento de análise comparativa entre as demais capitais nordestinas. A passagem do absoluto para o relativo fragiliza-se. Entretanto, desconsiderando os dados de Pernambuco (evidenciados em escala estadual e não municipal) e a não indicação de dados completos sobre João Pessoa, convém ressaltar: a) concentração importante de empreendimentos nas cidades de Salvador (BA), com 292, e Fortaleza (CE), com 229; b) participação destacada de Natal, com 159 estabelecimentos hoteleiros, número bem acima do registrado nas outras cidades nordestinas: Aracaju (64), São Luis (43), Maceió (28) e Teresina (14).
A primeira variável, relacionada a Salvador e Fortaleza, reflete nuanças apontadas pelos investimentos públicos nos estados nordestinos. A segunda variável, a de Natal, reverte tal indicativa ao suplantar Aracajú, cujo estado é o quarto em volume de investimentos públicos, no total de estabelecimentos hoteleiros. Na competição instituída entre as cidades litorâneas nordestinas, no sentido de atrair investimentos com o produto turístico praia, supõe-se que a cidade de Aracajú não consegue deslanchar, posto continuar eclipsada pela metrópole de Salvador e às investidas de seus governantes.

Tabela 2 - Investimentos Privados: estabelecimentos hoteleiros, unidades Habitacionais (Uh's), número de leitos, taxa de ocupação anual das capitais da Região Nordeste.

\begin{tabular}{|c|c|c|c|c|c|}
\hline CAPIAL & $N^{\circ}$ DE ESTABELECIMENTOS & UH'S & N DE LEITOS & $\begin{array}{c}\text { AHO DE } \\
\text { REFERÊHCIA }\end{array}$ & $\begin{array}{c}\text { TAXA DE } \\
\text { OCUPACÄО AHUAL }\end{array}$ \\
\hline Sẵ Lis & 43 & 2.134 & - & 2000 & $51 \%(2003)$ \\
\hline Teresira & 14 & $凶 7$ & 1.531 & 2002 & $-*$ \\
\hline Fortaleza & 2229 & 9.619 & 22.510 & 2000 & $50,3 \%(2000)$ \\
\hline Natal & 159 & 7.604 & 15.401 & 2000 & - \\
\hline Joẫ Pessc日 & - & - & - & - & $51,6 \%(2003)^{* * *}$ \\
\hline Perrambucot* & 644 & 15.954 & 40.537 & 2002 & $62,4 \%(2001)$ \\
\hline Maceió & 28 & - & - & 2000 & $68,5 \%(2001)$ \\
\hline Aracaju & 64 & 2.026 & - & 2000 & - \\
\hline Salvador & 292 & 10.472 & 22.516 & 2000 & $61,8 \%(2001)$ \\
\hline
\end{tabular}

Fonte: PDITS's dos Estados Nordestinos para o PRODETUR/NE-II.

(*) O PDITS do Pólo costa do Delta disponibiliza os valores de Taxa de Ocupação para alta estação ( $92 \%)$ e para baixa estação (35\%).

(**) O PDITS do Pólo Costa dos Arrecifes, disponibiliza os dados referentes a todo o Estado.

(***) Dado disponibilizado pela Empresa Paraibana de Turismo S.A. - PBTur.

\section{No domínio dos fixos: cruzamento dos investimentos públicos e privados no Ceará}

Dados resultantes de pesquisa versando sobre o imobiliário e o turismo nas regiões metropolitanas nordestinas de Salvador, Recife, Fortaleza e Natal, da qual participamos como coordenador do núcleo
Fortaleza, nos auxiliam no entendimento do desdobramento dos investimentos turísticos públicos e privados (implantação de empreendimentos turísticos) no Ceará. Um quadro peculiar cujos desdobramentos dos investimentos públicos convergem, grosso modo, para parcelas diferenciadas do espaço. 
No primeiro domínio - investimentos públicos - segue-se a lógica determinada pelo PRODETUR I, de estabelecimento de infraestrutura no trecho compreendido entre Caucaia e a fronteira Trairí-Itapipoca - zona turística prioritária II, no litoral oeste.
Fortaleza, como capital, destaca-se na recepção de investimentos, notadamente em função da construção de aeroporto internacional, articulador dos fluxos turísticos no espaço litorâneo do estado (Figura 4).

Figura 4 - Cartograma representativo da distribuição de recursos do PRODETUR I no Ceará.

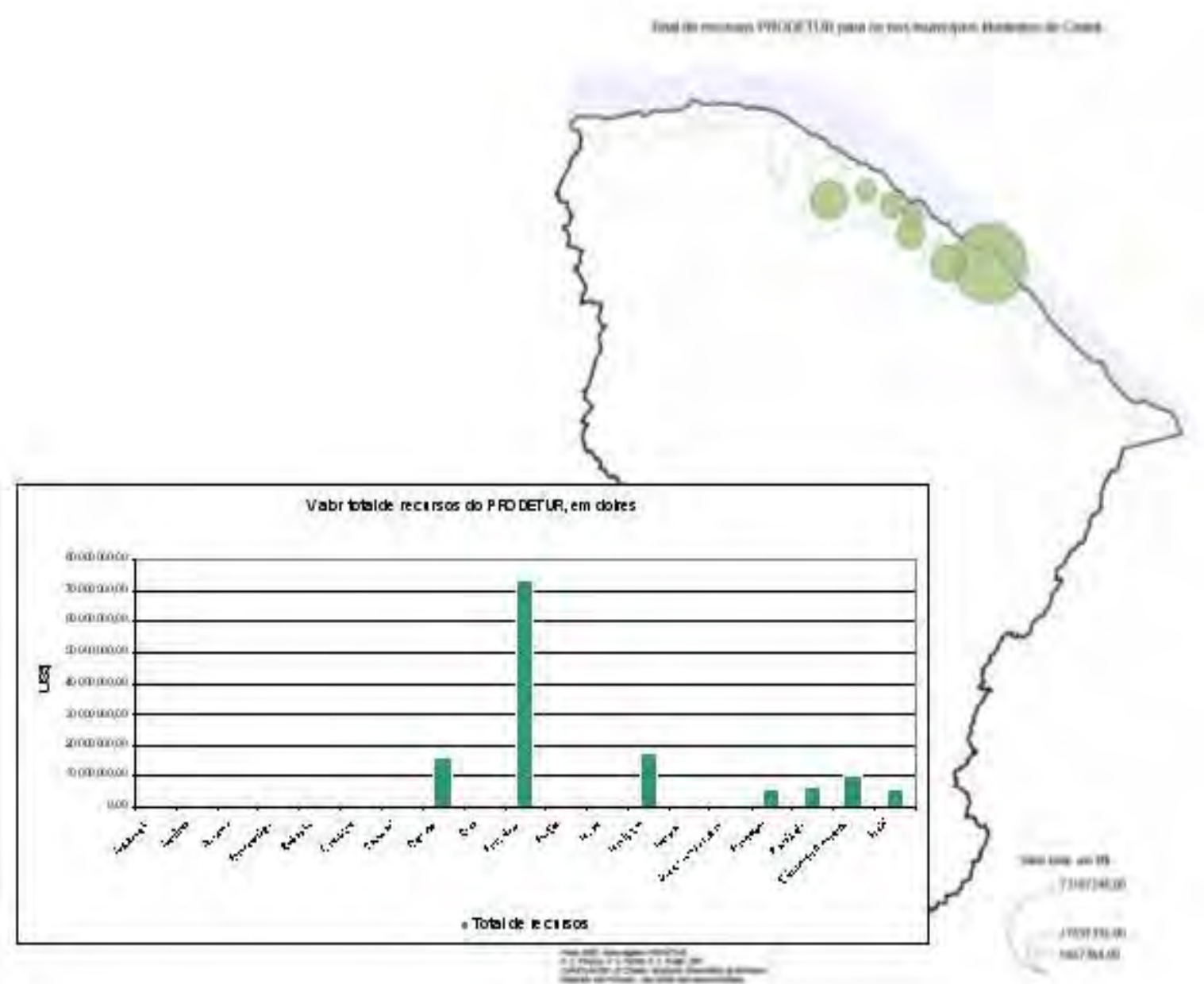


No segundo domínio - investimentos privados - há, até 2005, implantação de empreendimentos turísticos no litoral leste (com exceção de Icapuí), Fortaleza e Caucaia. Como previsão tal quadro incide, além de Fortaleza, sobre Aquiraz e Beberibe, no litoral leste, apresentando-se ainda, a partir deste momento, indicação de investimentos em localidades no extremo do litoral oeste, Jericoacoara e Camocim (Figura 5), acompanhando direcionamento de recursos públicos no PRODETUR II, para consubstanciação de lógica de ordenação turística regional, ao associar as destinações turísticas do extremo oeste à destinações turísticas do Delta do Parnaíba, no Piauí, e dos Lençóis Maranhenses, no Maranhão. Neste domínio há previsão de construção de vias e inclusive de aeroporto para dar vazão aos fluxos turísticos da área evidenciada.

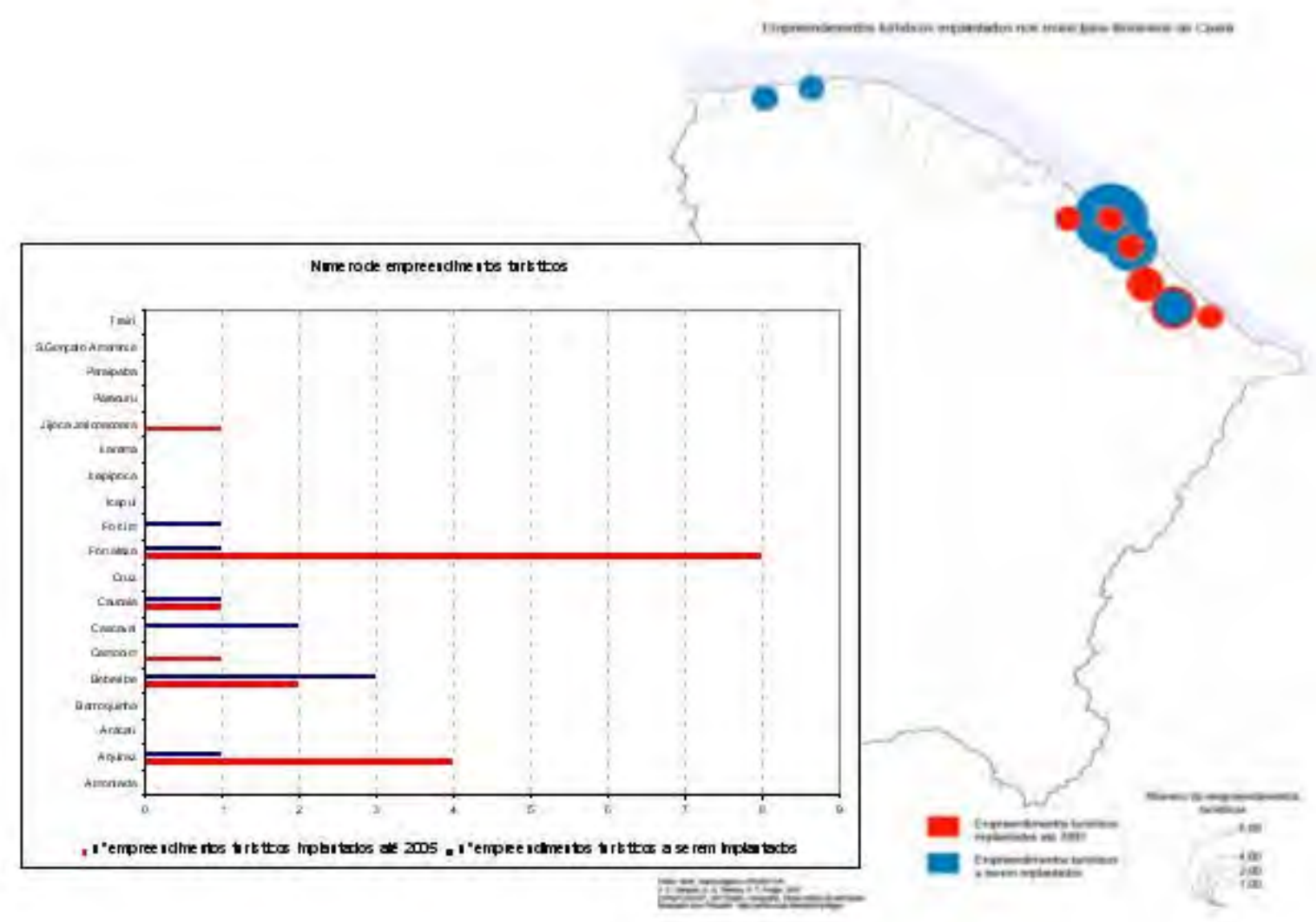

O estabelecimento de paralelo entre os dois cartogramas acima explicita uma lógica de ordenamento do território similar ao evidenciado no Nordeste. Tal lógica seria a da constituição de política pública de consolidação de turismo litorâneo, cujo desdobramento associa, grosso modo, volume importante de recursos públicos no litoral oeste, como estratégia do governo local em desenvolver o turismo nesta região, a investimentos importantes do setor privado no litoral leste. Esta lógica se cruza na metrópole, com indicação de quadro favorecendo, além da capital, os municípios litorâneos de Caucaia e Aquiraz. 
Imaginário social nordestino e políticas de

Em termos gerais, e pautando-se no estudo de caso do Ceará, os fixos resultantes da ação pública (aeroportos e vias litorâneas em destaque) e privada (notadamente os empreendimentos hoteleiros) são condição para atração e diluição de fluxos no Nordeste. Tais fluxos são direcionados às capitais nordestinas e diluem-se nos municípios litorâneos. Dado as mesmas, posto concentrarem aeroportos e hotéis (maior contingente) em seu território, se apresentarem, na contemporaneidade, como pontos de recepção e de distribuição dos fluxos turísticos.

\section{No domínio dos fluxos}

A análise do volume de passageiros no Nordeste evidencia o que foi dito anteriormente. Pautado em levantamento da Empresa Brasileira de Infra-Estrutura Aeroportuária (INFRAERO), nota-se fluxo alicerçado tanto na destinação (nacional e internacional) como na natureza do transporte (regular ou não regular - vôo charter), ambos nos anos de 2003 e 2004. Evidencia-se dinamismo do transporte aéreo no Nordeste, podendo estabelecer análise representativa da participação do mesmo na escala do Brasil e do comportamento de cada um dos estados do Nordeste.

No que concerne à participação do transporte aéreo nordestino no Brasil, notadamente os desembarques totais, percebese no domínio do: a) Transporte aéreo nacional - participação na ordem de $17 \%$, a saber, $17,79 \%$ em 2003 (5.470122 passageiros contra $30.742 .037), 17,41 \%$ em 2004 (6.367.104 passageiros contra 36.566.585) (Tabela 3); b) Transporte aéreo internacional - participação menor do que a nacional, variando da casa dos $4 \%$ à 7\%, especificamente 4,87\% em 2003 (262.299 passageiros contra 5.375.343) e $7,33 \%$ em 2004 (450.385 passageiros contra 6.138.217) (Tabela 4).

\begin{tabular}{|c|c|c|c|c|c|c|c|c|c|c|c|c|}
\hline \multirow{3}{*}{$\Delta F$} & \multicolumn{6}{|c|}{ 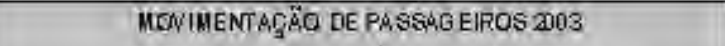 } & \multicolumn{6}{|c|}{ MOVIMENTAĞÃO DE PASSAGG EIROS 2004} \\
\hline & \multicolumn{3}{|c|}{ Entiterq us } & \multicolumn{3}{|c|}{ Dlesemberques: } & \multicolumn{3}{|c|}{ Ertiande } & \multicolumn{3}{|c|}{ Desemberq us } \\
\hline & Reg ulai & Nở tegular & Total & Regutar & $\begin{array}{l}\text { Näo } \\
\text { regular }\end{array}$ & Total & Ragular & $\begin{array}{l}\text { बago } \\
\text { Ieg ular }\end{array}$ & Total & Fegl & $\begin{array}{c}\text { Néco } \\
\text { tegular }\end{array}$ & Total \\
\hline $\mathrm{MSO}$ & 192.502 & 35.662 & 228 & 192.311 & 34.317 & & $10 . x^{2}$ & 37.636 & 287.739 & ont.008 & 35582 & $2000+109$ \\
\hline PI & 87.043 & 18,692 & 10 & 87.495 & 17527 & 10 & 09 & 24.163 & 2972 & 145 & 2434 & 492 \\
\hline $\mathrm{CE}$ & 674,124 & 125.491 & 800515 & 739.565 & 126,078 & 855.643 & 784.129 & 149.590 & 933719 & 856.354 & 152,701 & 1.009 .065 \\
\hline $\mathrm{RN}$ & $\$ 02.999$ & 78,045 & 381.044 & 300,580 & 74.967 & 375.547 & 362.456 & 104.473 & 466920 & 373.632 & 102.388 & 476.020 \\
\hline $\mathrm{PB}$ & 104.440 & 479 & 127.919 & 110.535 & 24.225 & 134.760 & 114.983 & 22.981 & 137.914 & 110.071 & 25.260 & 135.340 \\
\hline PE & 1.116 .404 & $118.05 T$ & 1.234 .451 & 1.341 .033 & 115.255 & 1.456 .288 & 1. 205.912 & 105.332 & 1.401 .244 & 1.576 .790 & 111.873 & 1.688663 \\
\hline AL & 192.263 & 62.165 & 254429 & 193.625 & 65.887 & 259.512 & 240.280 & 74.851 & 315,141 & 243.793 & 73717 & 317.510 \\
\hline $\mathrm{SE}$ & 132,128 & 31,840 & 163,968 & 133.688 & 33.174 & 156.862 & 138,244 & 23,370 & 151,514 & $\mid 36,455$. & 23908 & 150363 \\
\hline $\mathrm{BA}$ & 1.514 .288 & 120.927 & 1.635 .215 & 1.740 .754 & 139.105 & 1.879 .859 & 1. 695.428 & 150,151 & +245.579 & $2.009 .55 \mathrm{~T}$ & 160.515 & 2170172 \\
\hline NE & 4316.191 & 815.359 & 4.931 .550 & 4839587 & 630.535 & 5.470 .122 & 4.980284 & 692567 & 5.872851 & 5655.704 & 711.400 & 6.367 .104 \\
\hline$B R$ & 27.413 .252 & 2.213 .007 & 29.626 .289 & 00.0070000 & 2.207379 & $30.742 .03 T$ & $30,968,115$ & 2.772 .974 & $33.681,089$ & Q & 2815028 & 90.000 .0000 \\
\hline
\end{tabular}

Fonte: Empresa Brasileira de Infra-Estrutura Aeroportuária - INFRAERO, Anuário Estatístico da Embratur, 2004.

Nota: 0 s dados incluem desembarque de passageiros residentes e não residentes no Brasil. 
$\mathrm{Na}$ consideração dos vôos charters evidencia-se fluxo de caráter eminentemente turístico. Neste domínio, a participação do Nordeste em relação ao Brasil, nos termos indicados acima (desembarque), é mais significativa. Os vôos desta natureza dispõem na dimensão do: a) Transporte aéreo nacional percentuais da ordem de 20\%, 630.535 passageiros no Nordeste contra 2.207.379 no
Brasil, 28,56\% do fluxo total de 2003, e 711.400 passageiros no Nordeste contra 2.815.028 no Brasil, 25,27\% do fluxo total de 2004 (ver Tabela 3); b) Transporte aéreo internacional percentuais mais elevados, da ordem de $60 \%$, mais detalhadamente, $61,78 \%$ em 2003 (106.333 passageiros contra 172.105 no Brasil) e 65,68\% em 2004 (214.975 passageiros contra 327.273 no Brasil) (ver Tabela 4).

\begin{tabular}{|c|c|c|c|c|c|c|c|c|c|c|c|c|}
\hline \multirow{3}{*}{ UF } & \multicolumn{6}{|c|}{ Movirme ntagão de Pasaageiros 2003} & \multicolumn{6}{|c|}{ Movimentaģ̃o de Pasazgeiros 2004} \\
\hline & \multicolumn{3}{|c|}{ Enbarqus } & \multicolumn{3}{|c|}{ Degembarqua } & \multicolumn{3}{|c|}{ Embarqua } & \multicolumn{3}{|c|}{ Desemberque } \\
\hline & Regutar & $\begin{array}{l}\text { Náo } \\
\text { regutar }\end{array}$ & Total & Regular & $\begin{array}{l}\text { Năo } \\
\text { regular }\end{array}$ & Total & Regular & NGo regular & Total & Regular & Nõo reguter & Total \\
\hline $\mathrm{AL}$ & - & 13014 & 13014 & - & 11.598 & 11.598 & - & 12622 & 12.622 & - & 10.831 & 10.831 \\
\hline$B A$ & 65.294 & 5.451 & 70745 & 60.203 & 4.326 & 64.529 & 104.985 & 29.980 & 134.905 & 111.744 & 34.482 & 145.225 \\
\hline $\mathrm{CE}$ & 43.843 & $334 \pi$ & TT. 320 & 43.223 & 35.823 & 79.046 & 62.559 & 63.44 & 126.053 & 63.979 & 62.863 & 12684 \\
\hline Wh & - & 68 & 68 & - & 75 & 75 & . & 121 & 121 & - & 163 & 163 \\
\hline PB & - & 13 & 13 & - & 10 & 10 & - & 10 & 10 & - & 9 & 9 \\
\hline $\mathrm{PE}$ & $55.88 \mathrm{~T}$ & 7.968 & 63855 & 51.501 & 8.090 & 59.591 & 57.409 & 20.051 & 77.460 & 53.106 & 19.865 & 72.972 \\
\hline $\mathrm{PI}$ & - & 60 & 60 & - & 60 & 60 & - & - & - & - & - & - \\
\hline RN & 1.235 & 49.551 & 50786 & 1.039 & 45.190 & 41.229 & 5.205 & 86445 & 91.650 & 6.580 & 86.491 & 96.071 \\
\hline SE & - & 168 & 168 & - & 161 & 151 & 1 & 172 & 173 & 1 & 270 & 271 \\
\hline NE & 165.259 & 109.770 & 276.029 & 155.966 & 106.333 & 262.299 & 230.099 & 212895 & 442.994 & 235.410 & 214.975 & 450.385 \\
\hline BR & 4. $398.53 \mathrm{~T}$ & 173.066 & 4571.603 & 5.203 .198 & 172.150 & 5.375 .343 & 4. 680.891 & 321.257 & 5.002148 & 5.810 .944 & $32 \mathrm{~T} .2 \mathrm{~T} 3$ & 6.138 .217 \\
\hline
\end{tabular}

Fonte: Empresa Brasileira de Infra-Estrutura Aeroportuária - INFRAERO, Anuário Estatístico da Embratur, 2004.

Nota: Os dados incluem desembarque de passageiros residentes e não residentes no Brasil.

Tal comportamento representaria lógicas diferenciadas envolvendo a atividade turística na escala do país e internacional. A primeira, característica de países de dimensões continentais, evidencia dependência do transporte aéreo no estabelecimento de relações internas, marcante desde o final da segunda guerra mundial. Para Dacharry (1981), tratar-se-ia da inclusão, na lógica do transporte aéreo, da clientela de lazer à tradicional clientela dos negócios. Representaria, nestes termos, ampliação do volume de vôos em atendimento às demandas resultantes das transformações políticas, sociais e econômicas ocorridas no Brasil e fundadas na dimensão tecnológica (o avião). No nordeste, em virtude das dimensões continentais do Brasil, o fluxo direcionado para as capitais nordestinas é, a exemplo do acontecido em destinações insulares, fortemente dependente do transporte aéreo. O paradoxo da continentalidade evidenciando quadro próximo do vivido em regiões como as Antilhas e nas quais o sucesso da política turística em escala internacional está associado, também, à constituição de aparato capaz de viabilizar os fluxos a longa distância. A diferença é que internamente o Brasil dispõe de empresas aéreas consolidadas, concentrando-se os 
Imaginário social nordestino e políticas de

esforços dos governantes, principalmente, na construção de aeroportos, de preferência, no padrão internacional. A segunda se deve à inclusão recente do Nordeste no mercado turístico internacional. Para tanto, e no sentido de viabilizar o deslocamento de turistas em distâncias intercontinentais, o recurso do vôo charter é um complemento importantíssimo na ampliação da capacidade de atração de fluxos externos. Tal lógica é reforçada, de um lado, com construção de aeroportos internacionais e, de outro lado com a transformação dos já existentes à condição de internacional. Significa, nestes termos, ampliação de padrão restrito, até final dos anos 1980, às capitais nordestinas de Recife e Salvador. Na atualidade, em virtude da política de desenvolvimento agressiva adotada no Ceará e Rio Grande do Norte, as capitais de Fortaleza e Natal incluem-se no quadro dos vôos internacionais, revezando em importância com as cidades anteriormente citadas.

\section{De uma lógica de dominação perpendicular às zonas de praia a uma dominação paralela}

A presente política de constituição dos pólos turísticos no Nordeste, com locação de investimentos geradores de ações com repercussão em lógica de ordenação do território, fortalece modelo caracterizador das cidades litorâneas - marítimas tropicais contemporâneas (do final do século $X X$, início do século $X X I)$. Cidades que se abrem para o mar, ao constituírem lógica de ordenação do território paralela à zona costeira e fundada na articulação entre as vias litorâneas e os aeroportos, no sentido de atrair fluxos cada vez maiores de turistas e de investimentos (DESSE, 1996; DANTAS, 2006a).

A indicação desta lógica de dominação paralela transforma as zonas de praia em mercadoria nobre, dado que implica na modificação radical da paisagem litorânea. Com as novas práticas marítimas ligadas ao veraneio e ao turismo, as paisagens associadas à pesca e ao porto se encontram abaladas. Uma zona marcada pela presença dos portos e dos vilarejos de pescadores é afetada atualmente pela construção de novas formas (dos estabelecimentos turísticos somando-se às residências secundarias) acompanhando toda linha costeira.

Em conformidade com esta lógica de valorização, as cidades litorâneas nordestinas são transformadas em pontos de recepção e de distribuição do fluxo turístico, colocando os espaços litorâneos de todos os municípios do estado sob a dependência direta das capitais e sem a mediação de outros centros urbanos intermediários. Grosso modo, significa lógica de dominação paralela à zona de praia, prolongando-se sobre o litoral e baseada no aeroporto, que se adiciona à antiga lógica de dominação perpendicular, partindo do interior para o sertão e baseada no porto.

\section{O Turismo, um negócio de publicidade e de propaganda política}

De uma imagem derivada de uma consciência comum de pertencimento (CLAVAL, 1981), cujos elementos fundadores figuram em documentos antigos e em relatos de viagens, passa-se para um controle das imagens das cidades através de uma política de marketing baseada na mídia e, principalmente, na televisão. Em outros termos, surgem outros elementos constitutivos da imagem da cidade.

As imagens das cidades centravam-se anteriormente sobre uma tomada de consciência de um comportamento de grupo com base espacial, dado que suscitava uma solidariedade global que criava uma consciência comum de pertencimento, levando os habitantes a vislumbrar algo que os torna diferentes de um cidadão de outras paragens (CLAVAL, 1981).

As imagens veiculadas atualmente obedecem a uma outra lógica, reveladora de outras escalas e parâmetros. No Nordeste, após final dos anos 1980, podemos falar de articulação das cidades com escalas mais amplas, inclusive a internacional e que são 
definidas pelo desejo de torná-las competitivas em relação a outras cidades. Para tanto, cada cidade procura se impor com a elaboração de uma imagem especifica e associada, no caso em evidencia, ao turismo litorâneo, notadamente nos termos propostos por DANTAS (2000), ao indicar, no caso de Fortaleza, a evidenciação de uma cidade litorânea marítima cujos elementos humanos e naturais são valorizados como mercadoria turística. Observa-se, portanto, a construção de uma imagem turística da cidade.

\section{1 - A construção da imagem turística das cidades litorâneas nordestinas.}

A construção da imagem turística das cidades litorâneas nordestinas, principalmente das capitais, insere-se na mesma racionalidade das outras cidades litorâneas dos países em via de desenvolvimento, ou seja, conforme modelo internacional de desenvolvimento do turismo.

Com seu sucesso, a Espanha representa modelo de desenvolvimento do turismo segundo política de marketing turístico. Na implementação de estratégia de desenvolvimento do turismo nos termos do conceito de marketing (LAQUAR; HOLLIER, 1981), elabora-se imagem turística permitindo este país se aproveitar de suas costas ensolaradas e de sua geografia nacional (POUTET, 1995). Este sucesso a torna paradigma maior das políticas de desenvolvimento do turismo nos países em via de desenvolvimento, inclusive na América Latina. Ao considerarmos o percurso metodológico adotado por Poutet (1995) no caso espanhol, podemos apreender o ocorrido no Ceará.

Considerando o turismo como fenômeno de ordem econômica e política, Poutet (1995) tenta não reduzir a amplitude do fenômeno turístico, haja vista o mesmo ter servido, também, como instrumento de propaganda do franquismo, ao criar uma consciência turística indicadora do fluxo de estrangeiros como um símbolo do sucesso e viabilidade do regime político instaurado em 1939.
Por se caracterizar como instrumento de propaganda que a nova elite política soube explorar para desenvolver uma consciência turística e um símbolo de sucesso e viabilidade do novo governo, o mesmo se aplica ao Ceará. A única diferença a descartar, para não tornar esta via metodológica impraticável, concerne ao quadro político no qual estas políticas se desdobraram. Considerando transformações recentes que suscitaram, de um lado, a diminuição do papel do estado central e, de outro lado, o fortalecimento do papel do estado local baseado na prosperidade das cidades (CLAVAL, 1997), o percurso metodológico empreendido pode contribuir à compreensão do processo de elaboração da imagem turística do Ceará (DANTAS, 2002b). Esta imagem é cunhada graças a quadro de descentralização do poder que denota importante papel do estado local no desenvolvimento de políticas de planejamento e de marketing reforçadoras do papel central da capital, Fortaleza, na valorização das zonas de praia do Ceará.

Nesta perspectiva, uma nova imagem de Fortaleza foi elaborada: a da Cidade do Sol (DANTAS, 2002a). Trata-se de imagem concebida além daquela de nação, inscrita no sistema mundial, e construída pela nova elite política local em conformidade com uma consciência turística que a torna o espelho do novo governo. Assim, ela ultrapassa, a exemplo da Espanha, o contexto estritamente turístico e econômico e revela a propaganda política, ao se utilizar da publicidade para responder aos critérios do desenvolvimento econômico e anunciar a modernização.

Podemos falar, portanto, de um turismo que se desenvolve em virtude da ação conjugada entre publicidade e propaganda. Esta relação é sublinhada por Domenach (1979), ao afirmar que a propaganda, embora se diferencie ao ter um objetivo político e não simplesmente comercial, se aproxima da publicidade na medida em que ela procura criar, transformar ou confirmar opiniões se utilizando, em parte, dos mesmos meios. 
Imaginário social nordestino e políticas de

Esta filiação forma opiniões tanto internas (em escala local) como externas (em escala regional, nacional e internacional). A opinião interna é marcada pela criação de uma consciência turística que busca convencer os habitantes de Fortaleza da vocação turística do estado e da capital. A opinião externa é marcada pelo fortalecimento da imagem turística da cidade, transformada em paraíso para os turistas amantes de praias.

Esta formação de opinião moldada pela publicidade/propaganda suscita a construção de uma imagem de marca de Fortaleza baseada nas vantagens climáticas. Procura-se, assim, construir uma imagem para difundir o processo de modernização do Ceará, dado comprometedor da imagem trágica associada ao imaginário social da seca e que impedia o desenvolvimento do turismo.

\section{2 - A construção da imagem turística pelos ideólogos do governo.}

Recorrendo à metáfora do sol como sinônimo de semi-aridez, fala-se atualmente de uma modificação de paradigma que desvaloriza as praticas políticas precedentes. Rebouças et al (1994), afirma ter sido a figura do sol utilizada por decênios como representação da seca, responsável pelo êxodo rural e pretexto para obtenção de ajudas do governo federal. Para ele, na atualidade, a relação dos habitantes do Ceará com o Sol dá-se noutro ponto de vista. O Astro rei, anteriormente considerado como adversário, torna-se importante aliado ao garantir taxa de umidade ideal, assegurar a constância da fotossíntese favorável à agricultura industrial, possibilitar a geração de energia alternativa, garantir brilho ideal para a lente das câmeras e representar uma reserva infinita para o turismo permanente.

A presente modificação de paradigma é controlada pelos ideólogos do governo com a criação de espaços de discussão e de formação de opinião procurando fortalecer pacto denotando relação diferenciada da sociedade com o semi-árido. O Pacto de Cooperação, instituído em 1991, representou a expressão maior desta estratégia. Trata-se de parceria estabelecida entre a sociedade civil e o Estado e cujo objetivo era o de repensar e de reestruturar a economia do Ceará segundo o novo cenário mundial. Esta parceria, estabelecida inicialmente entre representantes do $\mathrm{ClC}$ e do governo, foi ampliada com a inserção de outros segmentos do meio patronal, de diversos organismos públicos, de centros de pesquisa, de universidades bem como organismos internacionais. Em suma, representava um grande fórum, contando com a participação do Governador Ciro Gomes (presidente do Pacto de Cooperação), do Prefeito de Fortaleza Juraci Magalhães bem como com a participação de delegados privados e permanentes da sociedade civil.

No seio deste fórum foram lançadas as bases para a construção de nova imagem do Ceará, e por extensão de Fortaleza. Buscando indicar diretrizes para o desenvolvimento do Ceará, se caracteriza como espaço de formação de opiniões necessárias para a elaboração da imagem turística do Ceará. Esta longa elaboração é parte de um diagnóstico que suscita, em um primeiro momento, a indicação dos problemas existentes e das possibilidades de resolução e, em um segundo momento, a indicação dos objetivos a atingir (ver Quadro $1)$.

Partindo da indicação do estado de subdesenvolvimento que caracteriza a região, os ideólogos do governo retomam a discussão sobre a viabilidade do semi-árido. Esta discussão, orientada pelo novo imaginário social do Nordeste, favorece o reforço do quadro de imagens positivas.

Com tal reforço, estes ideólogos colocam em xeque o discurso determinista das elites conservadoras do Ceará, abrindo espaço para indicação de uma nova prática política em conformidade com as exigências de resolução dos problemas. A análise destas exigências permite situar três idéias principais: a) não 
torna-se mais possível considerar visão trágica do semi-árido. O domínio deste meio, através da tecnologia, o torna um recurso inestimável para uma exploração rentável e sustentável; b) impraticável pensar política de desenvolvimento no Estado baseada somente na escala nacional. A crise do Estado Central no Brasil abre espaço para o fortalecimento do Estado Local, que pode estabelecer vínculos com a escala internacional, notadamente como parceiro de organismos e empreendedores internacionais; c) impossível consubstanciar políticas de desenvolvimento sem a participação do setor privado. A redução ou a supressão dos subsídios federais destinados aos governos de estado conduz estes últimos a buscar outras parcerias na iniciativa privada.
Estas idéias-chave evidenciam prática política oposta àquela dos Coronéis. Esta oposição repousa seja sobre a tecnologia e sua capacidade de superar os limites da natureza, seja sob a nova lógica do mercado, que suscita entrada das cidades dos países em via de desenvolvimento no sistema mundo.

Embora a incorporação destas cidades ao sistema mundial implique em certa independência em relação ao Estado Central, ela as submete a uma lógica de competição em escala internacional. As cidades se situam atualmente em uma rede mundial, na qual cada uma delas busca se especializar, conforme sua vocação, em um domínio especifico para atrair consumidores e investidores.

\begin{tabular}{|c|c|}
\hline PROBLEMAS & $\begin{array}{l}\text { Fome, pobreza e concentracão dos recursos e da riqueza. } \\
\text { Analfabetismo; } \\
\text { Sentimento de inferioridade. }\end{array}$ \\
\hline $\begin{array}{l}\text { EXIGÊNCIAS } \\
\text { PARA } \\
\text { RESOLUÇÕO } \\
\text { DOS } \\
\text { PROBLEMAS }\end{array}$ & 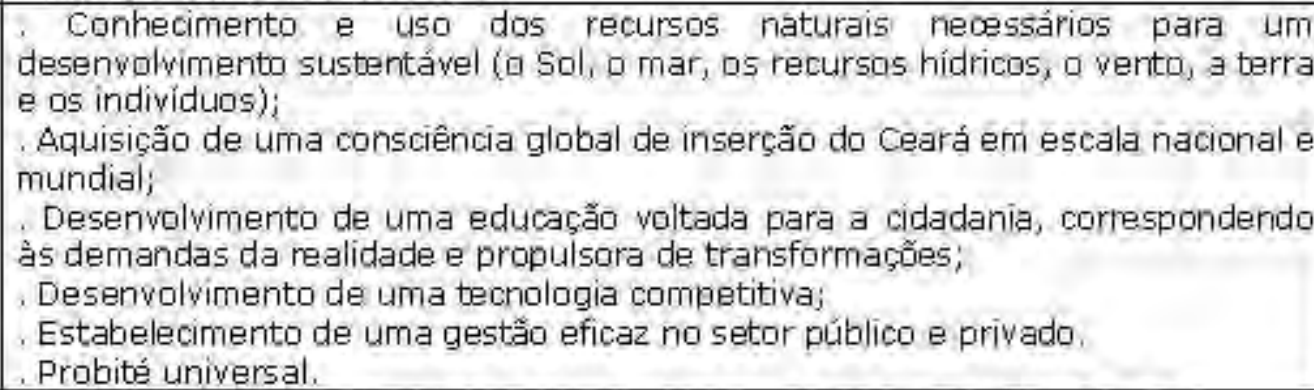 \\
\hline $\begin{array}{l}\text { OBJETIVOS A } \\
\text { REALISAR }\end{array}$ & $\begin{array}{l}\text { - Atingir uma boa gestão do Sol, da piscicultura, da energia eólica e solar; } \\
\text { Reduzir a desperdicio ao nivel europeu; } \\
\text { *azer com que a sociedade civil participe da construção de seu destino; } \\
\text { - Ter um Estado indutor do desenvolvimento, regulado do bem estar social, } \\
\text { articulado em seus poderes e catalisador da relação da sociedade com putras } \\
\text { instancias federativas e com os organismos internacionais; } \\
\text { Atingir uma municipalização do desenvolvimento e uma consciência municipal } \\
\text { de cidadania; } \\
\text { Desenvolver a turismo conforme nivel mundial do turismo das regiôes } \\
\text { tropicais. }\end{array}$ \\
\hline
\end{tabular}

Fonte: Rebouç̧as et al, 1995 ,

Procurando inserir o Ceará na rede mundial turística, o governo define os objetivos a atingir, reforçando a noção de vocação turística do Ceará cuja capital é a mola mestra. 
Imaginário social nordestino e políticas de

\subsection{1 - Crítica concernente à imagem turística de Fortaleza e do Ceará.}

Embora o sucesso econômico incite a tornar Fortaleza uma destinação turística, a sociedade local não se reconhece neste novo quadro que the foi oferecido.

Em um primeiro plano, críticas são dirigidas aos empreendedores turísticos que não mostram aos turistas a verdadeira Fortaleza, cidade rica de história cujo testemunho é oferecido pelo patrimônio arquitetural.

Segundo pesquisa realizada pelo Jornal O Povo, em duas (Ernanitur, Valtur) das três empresas que oferecem city tours em Fortaleza, chega-se à seguinte constatação:

...despontando como o destino mais procurado do País, com $26 \%$ da preferência dos turistas nacionais, Fortaleza ainda não é apresentada como merece aos seus visitantes. As principais agências que fazem o chamado turismo receptivo não mostram a história da cidade. As agências apresentam a Beira Mar, Aldeota, Praia de Iracema e uma pequena parte do centro de Fortaleza. Os guias de turismo mostram restaurantes, falam das praias que servem para banho e dizem onde o visitante pode se divertir. As informações sobre a história da cidade ficam restritas a alguns breves comentários sobre o Forte de Nossa Senhora da Assunção, o Passeio Público e a Praia de Iracema. (Jornal O Povo, 09/04/98).

Esta crítica testemunha abalo da imagem que esta sociedade possuía dela mesma: relacionada à historia de um Estado e de uma cidade cuja origem, a força e a vitalidade resultavam das relações estabelecidas entre os homens no e com o semi-árido.

Em um segundo plano, críticas derivam igualmente dos pescadores que se organizam em movimentos de luta pela terra. Embora a expulsão progressiva destes pescadores e a importante transformação de seu gênero de vida sejam uma tendência evidente, não podemos reduzir a realidade a este único aspecto. O movimento de expulsão provoca movimentos de resistência que continuam a se multiplicar. Há inserção, nestes termos, em dinâmica evidenciada em escala internacional, denotando o ocorrido em outros países tropicais, a título de exemplo: Senegal e países que foram antigas colônias da França, trabalhados respectivamente por CormierSalem (1996) e Desse (1996).

Estes movimentos se fortalecem como crítica ao modelo de desenvolvimento adotado. Trata-se da apresentação de outra demanda, aquela dos pescadores que lutam para garantir sua sobrevivência como habitantes das zonas de praia.

Peculiar neste movimento é que os pescadores, através da luta pela terra, redescobrem o mar. A redescoberta do mar reforça sua luta, haja vista o mesmo representar sua força. O mar é seu elemento, seu conhecimento antigo. É no mar que o pescador é reconhecido e que ele pode melhor se exprimir. É no mar que ele pode ser compreendido e se reencontra.

Enfrentando o oceano selvagem do Brasil, os pescadores apresentam suas reivindicações. A jangada, seu instrumento de trabalho, se transforma em meio de comunicação simbólica que reforça a luta destes homens ímpares. Tudo começou no inicio do século XX, nos anos 1940, com uma expedição organizada pelo mestre Jacaré. Este pescador, acompanhado de sua tripulação, partiu em uma pequena jangada para o Rio de Janeiro visando reivindicar os direitos trabalhistas obtidos no governo de Getúlio Vargas. Tudo foi retomado com a organização de uma segunda expedição em 1993: a Jangada da Sobrevivência, partindo da Praia do Canto Verde para o Rio de Janeiro, com o objetivo de sensibilizar a população para os perigos que ameaçam os pescadores.

Estes movimentos correspondem à luta pelo direito à diferença, ao direito de se apropriar das zonas de praia como locus de produção. Nota-se, portanto, uma espécie em via de extinção (o pescador), mostrar à 
sociedade inteira que as zonas de praia não podem ser limitadas aos banhos de mar e aos banhos de sol.

\section{Considerações Finais}

A análise empreendida no presente trabalho auxilia na compreensão dos elementos delineadores da construção do Nordeste turístico. Enfoque baseado no imaginário social nordestino permite apreender como uma região pobre, não turística, em período de tempo tão curto, aproximadamente vinte anos, transformase em ponto privilegiado das destinações turística internacional e, principalmente, nacional.

$\mathrm{Na}$ argamassa do novo imaginário social nordestino se dá redimensionamento da relação da sociedade com o semi-árido, apresentando0 , em conformidade com o discurso predominantemente tecnológico, como espaço virtual no processo de valorização turística litorânea.

A modificação do imaginário social significa, em escala nacional e internacional, a incorporação do litoral como espaço de consumo. Tal lógica se apóia em política de marketing adotada pelos governos estaduais. Nos aproximamos, portanto, de orientação metodológica indicada por Castro (1997a), ao remeter às possibilidades empíricas do conceito de imaginário na compreensão das formas de apropriação do espaço pela sociedade. Segundo esta autora, o imaginário social torna visível e interpretável os simbolismos presentes na relação dos homens entre eles e com seu meio e que se materializam em diferentes meios de organização socioespacial.

Em conformidade com esta racionalidade se consolidam as políticas públicas voltadas para o turismo, possibilitando que grupos políticos "mais avançados" possam suplantar uma racionalidade desenvolvimentista baseada na indústria e de caráter determinista. O turismo litorâneo apresenta-se, portanto, como tábua de salvação para a região, atendendo, de um lado, uma demanda econômica e, de outro lado, política. Pautado na teoria do marketing, que associa publicidade e propaganda, aponta-se para a construção de uma imagem turística da região e na qual as capitais se inscrevem na mesma largura de onda das cidades litorâneas dos países em via de desenvolvimento, fato que contribui à elaboração e promoção de uma imagem buscando assegurar o sucesso dos novos lugares de férias, bem como a atração de investimentos estrangeiros e do apoio internacional.

Esta prática leva a in por as capilais nordestinas com o destinações turísticas e suscita taxas de urbanização elevadas dos espaços litorâneos, qujas conseqüências são percebidas na tônica da organização espacial em voga, com um a reestruturação urbana que reforça as relações das capitais diretam ente, e sem mediações, com as zonas de praia dos m unicípios litorâneos. Garante-se, portanto, substrato para o estabelecin ento de com petição das cidades nordestinas (capitais) em escala internacional e no sentido de atrair maior contingente de turistas, volum e de recursos e núm ero de em preendim entos turísticos. Nasce, nestes term os, a m etáfora da Cidade do Sol, em conform idade com os projetos de planejamento que as transform am, gradativam ente, em in portantes destinações turísticas.

Evidencia-se, com redin ensionam ento do papel das capilais nordestinas, fenôm eno contem porâneo de fragm entação da regĩão nordeste com indicação de um 'Nordeste Turístico", associado às in agens representativas da $\mathrm{m}$ aritim idade nas capilais nordestinas. Thldado evidenciaria, nos term os indicados por Silva (1999), passagem de uma regĩa com base natural, geradora de modos de vida representativos, para outra regĩa de fiundam entação econôm ica e definidora de novos im ites e recortes nos term os explicitados pelas polf́icas de desenvolvim ento. 
Imaginário social nordestino e políticas de

Atualmente, o turismo apresenta-se no Nordeste como gerador de desenvolvimento, podendo resolver os problemas de emprego e de déficit econômico, algo semelhante ao ocorrido nas Antilhas dos anos 1960-1970. A partir das experiências vividas nesta área, percebe-se que a relação entre turismo e desenvolvimento econômico não é evidente. Para Ascher (1984), o turismo: a) utiliza uma mão-de-obra qualificada sem criar empregos locais; b) permite tão somente o desenvolvimento de subempregos; c) contribui ainda para certa instabilidade econômica e social, pelo fato desta atividade ser sazonal; d) suscita a construção de um quadro de dependência dos países em relação aos tours opérateurs que dominam este setor em escala mundial, com o estabelecimento de cadeias hoteleiras e o controle do transporte aéreo.

Embora se constate in locus a veracidade das críticas supramencionadas, percebe-se que a crença nos benefícios do turismo se sobrepõe e provoca no Nordeste um boom turístico, alicerçado por políticas públicas de valorização das zonas de praia, cujos fixos e fluxos provocam a inserção de novos atores e a expulsão dos antigos habitantes.

\section{Bibliografia}

ALMEIDA, Maria Geralda de. Turismo no Ceará: reflexões sobre o processo e implicações para o litoral cearense, Caderno Norte Rio-Grandense de Temas Geográficos. Natal: UFRN/CCHLA/DGE, v. 8, n 1, (janv./déc.) 1994.

ANUÁRIO DO CEARÁ, 1994. Fortaleza: IOCE, 1994.

ASCHER, François. Tourisme: sociétés transnationales et identités culturelles. Paris: UNESCO, 1984.

BECKER, Bertha; EGLER, Claudio A. G. Brasil uma nova potência regional na economiamundo. Rio de Janeiro: Ed. Bertrand Brasil, 1992.

BIRD, James. Centrality and cities. Londres: Routledge and Kegan Paul, 1977.

BIRD, James. Of central places, cities and seaports, Geography, vol.58, 1973.

CAMPOS, Eduardo. A Memória imperfeita. Fortaleza : Expressão Gráfica Editora, 1993.

CASTRO, Iná Elias de. Imaginário político e território: natureza, regionalismo e representação, in: CASTRO, Iná Elias de; GOMES, Paulo César da Costa; CORRÊA, Roberto Lobato (organizadores). Explorações Geográficas: percursos no fim do século. Rio de Janeiro: Bertrand Brasil, 1997(a).
CASTRO, Iná Elias de. Seca versus seca, novos interesses, novos territórios, novos discursos no Nordeste, in: Castro, Iná Elias et al. (organizadores). Brasil - questões atuais da reorganização do território. Rio de Janeiro: Bertrand Brasil, 1997(b).

CAZES, Georges. Les littoraux en proie au tourisme, Hérodote $n^{\circ}$ 93: Littoral, frontières marines. Paris: La Découverte, 1999.

CAZES, Georges. Les nouvelles colonies de vacances?. Paris: Harmattan, 1989.

CLAVAL, Paul. La logique des villes - essai d'urbanologie. Paris: LITEC, 1981.

CLAVAL, Paul. La métropolisation et la nouvelle distribution des acteurs sur la scène politique mondiale, in: CLAVAL, Paul; SANGUIN, André-Louis. Métropolisation et politique. Paris: Éditions L'Harmattan, 1997, p. 37-52.

CORIOLANO, Luzia Neide. Turismo e organização espacial em Fortaleza, Espaço Aberto. Fortaleza: AGB, 1989.

CORMIER-SALEM, Marie-Christine. Maritimité et littoralité tropicales: la Casamance (Sénégal), in: Peron, Françoise et Rieucau, Jean (sous la direction de). La maritimité aujourd'hui. Paris: Éditions L'Harmattan, 1996.

CUNHA, Euclides da. Os Sertões, vol. I et vol. II. Porto: Lello \& Irmão - Editores, 1983 [1ère édition, 1902]. 
DACHARRY, Monique. Géographie du transport aérien, Collection Géographie Économique et Sociale. Paris: LITEC, 1981.

DANTAS, Eustógio Wanderley Correia Dantas. Fortaleza et le Ceará. Essai de géopolitique d'um espace de colonisation tardive: de la découverte à la mutation touristique contemporaine. Paris: Tese de Doutorado, Paris IV - Sorbonne, 2000.

DANTAS, Eustógio Wanderley Correia. Mar à vista. Fortaleza: Museu do Ceará, 2002(a).

DANTAS, Eustógio Wanderley Correia Dantas. Construção da Imagem Turística de Fortaleza, Mercator, no 1. Fortaleza: UFC, 2002(b).

DANTAS, Eustógio Wanderley Correia Dantas. O Mar e o Marítimo nos Trópicos, GEOUSP, no 15. São Paulo: USP, 2004.

DESSE, Michel. L'inégale maritimité des villes des départements d'outre-mer insulaires, in: Peron, Françoise et Rieucau, Jean (sous la direction de), La maritimité aujourd'hui. Paris : Éditions L'Harmattan, 1996.

DOMENACH, Jean-Marie. La propagande politique. Paris: PUF, 1979.
GOVERNO DO ESTADO DO CEARÁ, Plano de Mudanças. Fortaleza: 1989.

JORNAL O POVO, 09/04/98.

KADT, Emanuel de. Le Tourisme. passeport pour le développement ?. Paris: Éditions Économica, 1979.

LAQUAR, Robert; HOLLIER, Robert. Le marketing touristique. Paris: PUF, 1981.

OLIVEIRA, Francisco de. Elegia Para Uma Re(li)gião). Rio de Janeiro: Paz e Terra, 1981.

PAIVA, Maria das Graças de Menezes Venâncio. Inquietações sobre o turismo e o urbano na região Nordeste, in: LIMA, Luiz Cruz (organizador) Da cidade ao campo - a diversidade do saber-fazer turístico. Fortaleza: UECE, 1998.

POUTET, Hervé. Images touristiques de I'Espagne: de la propagande politique à la promotion touristique. Paris: Éditions L'Harmattan, 1995.

REBOUÇAS, Osmundo et al. Gestão Compartilhada - O Pacto do Ceará. Rio de Janeiro: Qualitymark Ed., 1994.

VARIG, Le Brésil, 1997.

Trabalho enviado em agosto de 2007 e aceito em setembro de 2007 